\title{
PENGARUH TOTAL ASSET TURNOVER, DEBT TO EQUITY RATIO, CASH FLOW TERHADAP RETURN SAHAM DENGAN TRADING VOLUME ACTIVITY SEBAGAI VARIABEL INTERVENING (STUDI PADA PERUSAHAAN PLANTATION YANG TERDAFTAR DI BEI PERIODE 2016 - 2017)
}

\section{EFFECT OF TOTAL ASSET TURNOVER, DEBT TO EQUITY RATIO, CASH FLOW ON STOCK RETURNS BY TRADING VOLUME ACTIVITY AS INTERVENING VARIABLES (STUDY ON PLANTATION COMPANIES LISTED ON THE STOCK EXCHANGE FOR} THE PERIOD OF 2016 - 2017)

\author{
Muhammad Hidayat', Yulia Efni ${ }^{2}$, Andewi Rokhmawati ${ }^{3}$ \\ 1 Universitas Riau; Pekanbaru \\ ¿Universitas Riau; Pekanbaru \\ 3Universitas Riau; Pekanbaru \\ m.hidayat2901@gmail.com
}

\begin{abstract}
ABSTRAK
Penelitian ini bertujuan untuk menguji dampak pengaruh total asset turnover, debt to equity ratio, cash flow terhadap return saham dengan trading volume activity sebagai variabel intervening. Populasi pada penelitian ini adalah seluruh perusahaan plantation yang terdaftar di Bursa Efek Indonesia periode 2016 dan 2017. Jumlah sampel terdiri dari 14 perusahaan yang ditentukan dengan metode purposive sampling. Penelitian ini melakukan pengujian analisis jalur dengan menggunakan program SPSS Versi 21. Hasil penelitian menunjukkan bahwa total asset turnover berpengaruh terhadap trading volume activity. Debt to equity ratio dan trading volume activity berpengaruh terhadap return saham. Trading Volume Activity tidak dapat memediasi atau menjadi variabel intervening antara total asset turnover, debt to equity ratio dan cash flow terhadap return saham.

Kata Kunci : Total Asset Turnover, Debt to Equity Ratio, Cash Flow, Trading Volume Activity, Return Saham.
\end{abstract}

\section{ABSTRACT}

This research aims to examine the effect of total asset turnover, debt to equity ratio, cash flow on stocks return with trading volume activity as an intervening variable. The population is all plantation companies that listed on the Indonesia Stock Exchange period 2016 - 2017. The number of samples are 14 companies that are determined by purposive sampling method. This research used path analysis using SPSS V.21 software. The result of this research show that total asset turnover effected to trading volume activity. Debt to equity ratio and trading volume activity effected to stock return. Trading volume activity can not be an intervening variable between total asset turnover, debt to equity ratio and cash flow to stock return.

Key Words : Total Asset Turnover, Debt to Equity Ratio, Cash Flow, Trading Volume Activity, Stock Return. 


\section{PENDAHULUAN}

Teori investasi selalu dikatakan bahwa setiap instrument investasi akan menghasilkan return dan risiko. Return merupakan imbalan hasil yang diperoleh investor dari hasil investasi sedangkan risiko adalah tingkat penyimpangan yang akan ditanggung oleh investor dari hasil transaksi investasi yang dilakukan. Dalam instrument investasi, kegiatan investasi diarahkan untuk jangka waktu yang panjang dan yang memiliki return yang baik dan memiliki prospek kedepannya (Jogiyanto, 2007).

Signaling theory mengemukakan tentang bagaimana seharusnya sebuah perusahaan membarikan sinyal kepada pengguna laporan keuangan. Sinyal berupa informasi yang menyatakan bahwa perusahaan tersebut lebih baik dari perusahaan yang lain. Teori sinyal mencermati bagaimana sinyal berkaitan dengan kualitas yang dicerminkan dan elemen apa saja yang menarik. Sinyal muncul dikarenakan lingkungan usaha yang sangat kompetitif, dimana masing-masing perusahaan akan saling menunjukkan kualitas informasi untuk dapat menarik pihak-pihak eksternal (Jama'an, 2008).

Perusahaan yang memiliki kinerja yang baik akan disukai oleh banyak investor sehinggat terjadi tawar menawar yang tinggi pada perusahaan tersebut. Tawar menawar yang tinggi akan meningkatkan transaksi yang dilakukan. Menurut Copeland (1979) menyatakan bahwa jika volume perdagangan meningkat, maka jumlah pemegang saham juga akan bertambah sehingga likuiditas saham akan meningkat dan memberikan kemungkinan lebih tinggi untuk mendapatkan return.

Pada tahun 2016, tingkat kenaikan (return) IHSG atau yang dikenal dengan Jakarta Composite Index (JCl) sebesar $15,32 \%$. Sektor industri yang memperoleh return terkecil adalah sektor agriculture dan mining, yaitu hanya sebesar 5,47\% untuk sektor agriculture dan 1,31\% untuk sektor mining. Pada tahun 2017, terjadi kenaikan return IHSG menjadi 19,99\%. Meskipun terjadi kenaikan pasar, sektor agriculture menghasilkan penurunan return terbesar yaitu sebesar $13.30 \%$ dari tahun sebelumnya.

Meskipun return saham perusahaan kelapa sawit (plantation) mengalami penurunan pada tahun 2017, total penjualan bersih (net revenue) dan laba tahun berjalan (profit for the period) keseluruhan emiten jika dilihat dari laporan keuangan tahun 2016 dan 2017 mengalami pertumbuhan. Penjualan bersih dan laba tahun berjalan yang dipublikasikan oleh emiten dapat menjadi sinyal bagi investor apakah saham perusahaan menarik untuk dibeli dan dikoleksi atau tidak. Sesuai dengan informasi laporan keuangan perusahaan, seharusnya kinerja harga saham (return) pada perusahaan kelapa sawit (plantation) juga mengalami kenaikan. Tetapi, pada kondisi kenyataannya kinerja harga saham (return) untuk sub sektor kelapa sawit mengalami penurunan pada tahun 2017. Hal ini menjadi fenomena penelitian yang akan dilakukan pengkajian lebih lanjut.

Rasio total asset turnover mengukur seberapa baik efisiensi seluruh aktiva perusahaan digunakan untuk mendukung kegiatan penjualan. Total asset turnover yang tingi mengindikasikan bahwa manajemen perusahaan dapat mendayagunakan seluruh aktiva yang dimiliki (Syamsuddin, 2009). Penelitian yang dilakukan oleh (Vayanos, 2005) menyatakan bahwa perusahaan dengan total asset turnover yang tinggi diminati oleh investor karena perusahaan tersebut memiliki probabilitas yang lebih tinggi untuk menjadi sangat likuid. Penelitian yang dilakukan oleh (Chairiyah, 2013) menyatakan bahwa semakin tinggi rasio total asset turnover, semakin efisien penggunaan seluruh aktiva dalam menghasilkan penjualan. Penjualan yang meningkat dari perusahaan akan meningkatkan laba perusahaan sehingga laba berupa dividen 
yang siap dibagikan kepada investor juga akan semakin meningkat. Bagi investor, laba perusahaan yang meningkat maka akan memberikan return yang tinggi. Sedangkan penelitian yang dilakukan oleh (Aprisilya,2016) menyatakan bahwa total asset turnover tidak berpengaruh terhadap expected return.

Debt to Equity Ratio (DER) diperkirakan juga dapat mempengaruhi return saham. DER merupakan rasio solvabilitas yang mengukur kemampuan kinerja perusahaan dalam mengembalikan hutang jangka panjang dengan melihat perbandingan antara total hutang dengan total ekuitas. Rasio ini dapat memberikan gambaran tentang struktur modal yang dimiliki oleh perusahaan sehingga dapat mengetahui risiko atas ketidakmampuan dalam membayar hutang (Suharli, 2006). Hasil penelitian (Purwitajati, 2016) menyimpulkan bahwa DER memiliki pengaruh negatif dan signifikan terhadap return saham, sedangkan penelitian (Saribu, 2011), (Hijriah, 2007), (Harahap, 2001), (Bhandari, 1988) menyimpulkan bahwa DER berpengaruh positif secara signifikan terhadap harga atau return saham. Penelitian yang dilakukan oleh (Aprisilya,2016) menyatakan bahwa DER tidak berpengaruh terhadap trading volume activity dan expected return. Penelitian yang dilakukan oleh (Elfitri, 2012) menyimpulkan bahwa rasio DER berpengaruh signifikan terhadap trading volume activity. Pada penelitian yang dilakukan, investor yakin bahwa perusahaan yang memiliki hutang yang lebih besar akan memberikan nilai yang lebih baik sehingga volume perdagangan saham akan lebih tinggi.

Cash Flow atau informasi laporan arus kas adalah informasi yang menyajikan penerimaan dan pengeluaran kas dan setara kas dalam suatu periode tertentu. Pernyataan Ikatan Akuntansi Indonesia (IAI) dalam Standar Akuntansi Keuangan (PSAK) No 2 (Revisi 2012) disebutkan bahwa perusahaan harus menyusun laporan arus kas dan harus menyajikan laporan tersebut sebagai bagian yang tidak terpisahkan dari laporan keuangan untuk setiap periode penyajian laporan keuangan. Laporan arus kas memiliki banyak informasi yang bisa digunakan oleh investor sebagai dasar pengambilan keputusan. Informasi yang terkandung dalam arus kas terdiri dari aktivitas operasi, aktivitas investasi dan aktivitas pendanaan. Dengan melihat informasi yang terkandung dalam laporan arus kas, para investor dan calon investor akan yakin terhadap pilihan investasi dan akan meningkatkan permintaan dan penawaran dalam perdagangan saham yaitu volume perdagangan (Bastomi, 2014). Penelitian yang dilakukan (Bowen, 1989) menyatakan bahwa unsur - unsur arus kas dari operasi memiliki pengaruh dan kemampuan untuk memprediksi return dan meningkatkan volume perdagangan. Sedangkan penelitian yang dilakukan oleh (Rohman, 2005) (Bastomi, 2014) menguji pengaruh langsung dan tidak langsung arus kas operasi dan laba terhadap volume perdagangan saham, menghasilkan bahwa besar kecilnya arus kas operasi dan laba akuntansi tidak berpengaruh terhadap tingkat volume perdagangan saham.

Perhitungan trading volume activity dilakukan dengan membandingkan jumlah saham yang diperdagangkan dalam suatu periode tertentu dengan keseluruhan jumlah saham yang beredar di perusahaan tersebut pada kurun waktu yang sama (Rowland, 2010). Nilai dari trading volume activity berbanding lurus dengan dengan likuiditas saham, dengan demikian semakin tinggi nilai trading volume activity sebuah saham mengartikan bahwa saham tersebut dapat dijual dengan mudah karena banyak yang bersedia membeli saham sehingga saham mudah dicairkan menjadi kas. Aset dengan likuiditas yang tinggi akan memberikan expected return yang tinggi pula (Jones, 2002).

Adapun yang menjadi fenomena penelitian kali ini adalah jika dilihat dari total penjualan bersih (net revenue) dan laba tahun berjalan (profit for the period) keseluruhan emiten kelapa sawit (plantation) yang terdaftar di BEI mengalami kenaikan pada tahun 2017. Informasi ini 
seharusnya dapat menjadi sinyal yang bagus bagi investor untuk membeli saham kelapa sawit. Namun, dengan kenaikan penjualan bersih dan laba tahun berjalan, harga saham emiten kelapa sawit (plantation) justru mengalami penurunan.

Rumusan masalah pada penelitian ini adalah apakah terdapat pengaruh total asset turnover, debt to equity ratio, cash flow terhadap trading volume activivity? Kemudian apakah terdapat pengaruh total asset turnover, debt to equity ratio, cash flow, trading volume activity terhadap return? Kemudian apakah trading volume activity dapat memediasi total asset turnover, debt to equity ratio, cash flow terhadap return?

\section{LANDASAN TEORI}

\section{Signaling Theory}

Teori sinyal (signaling theory) berawal dari tulisan George Akerlof pada karyanya di tahun 1970 "The Market for Lemons" yang memperkenalkan istilah informasi asimetris (assymetri information). Dari penelitiannya tersebut, Akerlof (1970) menemukan bahwa ketika pembeli tidak memiliki informasi terkait spesifikasi produk dan hanya memiliki persepsi umum mengenai produk tersebut, maka pembeli akan menilai semua produk pada harga yang sama, baik produk yang berkualitas tinggi maupun yang berkualitas rendah, sehingga merugikan penjual produk berkualitas tinggi. Kondisi dimana salah satu pihak (penjual) yang melangsungkan transaksi usaha memiliki informasi lebih atas pihak lain (pembeli) ini disebut adverse selection (Scott, 2009). Adverse selection dapat dikurangi apabila penjual mengkomunikasikan produk mereka dengan memberikan sinyal berupa informasi tentang kualitas produk yang mereka miliki (Akerlof, 1970).

Pemikiran Akerlof,(1970) tersebut dikembangkan oleh Spence, (1973) dalam model keseimbangan sinyal (basic equilibrium signaling model). Spence (1973) memberikan ilustrasi pada pasar tenaga kerja (job market) dan mengemukakan bahwa perusahaan yang memiliki kinerja yang baik (superior performance) menggunakan informasi finansial untuk mengirimkan sinyal ke pasar. Dari penelitiannya tersebut, Spence (1973) juga menemukan bahwa cost of signal pada bad news lebih tinggi dari pada good news dan perusahaan yang memiliki bad news mengirimkan sinyal yang tidak kredibel. Hal tersebut memotivasi manajer untuk mengungkapkan informasi private untuk mengurangi asimetri informasi dengan harapan dapat mengirimkan sinyal yang baik (good news) tentang kinerja perusahaan ke pasar.

Teori sinyal menekankan kepada pentingnya informasi yang dikeluarkan oleh perusahaan terhadap keputusan investasi pihak luar. Informasi merupakan unsur penting bagi investor dan pelaku bisnis karena informasi menyajikan keterangan, catatan atau gambaran baik untuk keadaan masa lalu, saat ini maupun keadaan masa yang akan datang bagi kelangsungan hidup suatu perusahaan. Pada sewaktu informasi diumumkan dan semua pelaku pasar sudah menerima informasi tersebut, pelaku pasar terlebih dahulu menginterpretasikan dan menganalisis informasi tersebut sebagai sinyal baik (good signal) atau sinyal buruk (bad signal). Informasi yang lengkap, relevan, akurat dan tepat waktu sangat diperlukan oleh investor sebagai alat analisis untuk mengambil keputusan investasi (Jensen, 1986)

\section{Investasi}

Terdapat beberapa definisi tentang investasi. menurut (Fabozzi, 1994) mengatakan bahwa manajemen investasi adalah proses pengelolaan uang. Menurut (Smith, 2012) mengatakan "investing activities: transaction and events the purchase and sale of securities and building 
equipment. Menurut (Frank, 2007) menyatakan bahwa investasi adalah "investment is the current commitment of dollar for a period of time to derive future payment that will compensate the investor for (1) the time the funds are commited, (2) the expected rate of inflation, (3) the uncertainty of the future payment".

Dalam proses pencarian keuntungan dengan melakukan investasi adalah sesuatu yang dilakukan dengan membutuhkan analusus dan perhitungan yang mendalam dan menerapkan prinsip kehati-hatian (prudent principle). Pentingnya sikap kehati-hatian merupakan modal penting bagi seorang investor dalam berinvestasi di pasar modal, Dalam aktivitasnya, investasi pada umumnya dikenal ada dua bentuk (Fabozzi, 1994), yaitu :

1. Real Investment, investasi nyata secara umum melibatkan aset berwujud seperti : tanah, mesin, atau pabrik.

2. Financial Investment, investasi keuangan melibatkan kontrak tertulis, seperti saham biasa (common stock) dan obligasi (bond).

Pada dua bentuk investasi diatas, (Sharpe,2005) menegaskan bahwa pada perekonomian primitive hampir semua investasi lebih ke investasi nyata, sedangkan pada perekonomian modern, lebih banyak dilakukannya investasi keuangan. Dimana lembaga-lembaga untuk investasi yang berkembang pesat memberi fasilitas untuk berinvestasi nyata. Jadi kedua bentuk investasi bersifat komplementer, bukan kompetitif. Sehingga kita bisa melihat salah satu ukuran ekonomi suatu negara tersebut adalah maju dimana keberadaan dan kualitas dari bursa efeknya diakui oleh para pebisnis.

\section{Return Saham}

Menurut (Elton,1995) saham adalah menunjukkan hak kepemilikan pada keuntungan dan aset dari sebuah perusahaan. Secara sederhana, saham dapat didefinisikan sebagai berikut : Saham adalah surat berharga sebagai bukti penyertaan atau kepemilikan individu maupun institusi dalam suatu perusahaan. Return merupakan tingkat keuntungan yang diperoleh pemodal atau investor atas investasi yang dilakukan. Setiap investasi baik jangka pendek maupun jangka panjang mempunyai tujuan pokok untuk mendapatkan keuntungan yang disebut sebagai return baik langsung maunpun tidak langsung (Ang, 2008).

Secara sederhana investasi dapat diartikan sebagai suatu kegiatan menempatkan dana pada satu atau lebih dari satu aset selama periode tertentu dengan harapan dapat memperoleh penghasilan atau peningkatan nilai investasi (Husnan, 2008). Dalam berinvestasi, investor yang rasional akan mempertimbangkan dua hal yaitu pendapatan yang diharapkan (expected return) dan risiko yang terkandung dari alternatif investasi yang dilakukan. Komponen return terdiri dari dua macam yaitu capital gain (keuntungan selisih harga) dan currrent income (perdagangan lancar). Capital gain merupakan keuntungan yang diterima karena adanya selisih antara harga penjualan dengan harga pembelian saham dari suatu instrumen investasi, yang berarti bahwa instrumen investasi harus diperdagangkan di pasar. Dengan adanya perdagangan maka akan timbul perubahan nilai suatu instrumen investasi yang menghasilkan capital gain. Untuk menentukan besarnya capital gain dilakukan dengan analisis return historis yang terjadi pada periode sebelumnya sehingga dapat ditentukan besarnya tingkat kembalian yang diinginkan.

Komponen kedua dari return adalah current income yaitu keuntungan yang diperoleh melalui pembayaran yang bersifat periodik misalkan pembayaran bunga deposito, dividen, bunga obligasi dan sebagainya disebut sebagai pendapatan lancar, maksudnya adalah keuntungan yang diterima biasanya dalam bentuk kas atau setara kas, sehingga dapat dituangkan secara 
cepat seperti bunga atau jasa giro dan dividen tunai. Serta yang setara kas adalah saham bonus atau dividen saham yaitu dividen dibayarkan dalam bentuk saham-saham dan dapat dikonversi menjadi uang kas.

\section{Total Asset Turnover}

Total assets turnover mengukur intensitas perusahaan dalam menggunakan aktivanya. Ukuran penggunaan aktiva paling relevan adalah penjualan, karena penjualan penting bagi laba. Total assets turnover atau investment turnover (TATO atau ITO), merupakan rasio antara jumlah aktiva yang digunakan dengan jumlah penjualan yang diperoleh selama periode tertentu. Rasio ini merupakan ukuran sampai seberapa jauh aktiva telah dipergunakan dalam kegiatan perusahaan atau menunjukan berapa kali aktiva berputar dalam periode tertentu. Apabila dalam menganalisis rasio ini selama beberapa periode menunjukan suatu trend yang cenderung meningkat, memberikan gambaran bahwa semakin efisiensi penggunaan aktiva sehingga hasil usaha akan meningkat (Sawir, 2008).

\section{Debt To Equity Ratio}

Menurut (Fred, 2011), debt to equity ratio adalah rasio yang menggunakan hutang dan modal untuk mengukur besarnya rasio. Sedangkan menurut (Fahmi, 2014) debt to equity ratio adalah rasioyang dipergunakan untuk mengukur tingkat penggunaan utang terhadap total shareholder's equity yang dimiliki perusahaan. Menurut (Riyanto, 2011), rasio utang dimaksudkan sebagai kemampuan suatu perusahaan untuk membayar semua utang-utangnya (baik hutang jangka pendek maupun utang jangka panjang). Teori (Miller, 1988) menyatakan nilai perusahaan ditentukan oleh struktur modal dan salah satu struktur modal perusahaan adalah diperoleh melalui hutang.

\section{Cash Flow}

Arus kas pada laporan keuangan terdiri dari arus kas operasional, arus kas investasi dan arus kas pendanaan. Arus kas operasi meliputi kas yang dihasilkan dan dikeluarkan yang masuk dalam determinasi penentuan laba bersih. Arus kas yang berasal dari aktivitas operasi meliputi arus kas yang timbul karena adanya pengiriman atau produksi barang untuk dijual dan penyediaan jasa, serta pengaruh transaksi dan peristiwa lainnya terhadap kas yang mempengaruhi pendapatan. Sedangkan Arus kas Investasi merupakan arus kas yang mencerminkan penerimaan dan pengeluaran kas sehubungan dengan sumber daya yang bertujuan untuk menghasilkan pendapatan dan arus kas masa denpan dan melibatkan aset jangka panjang. Terakhir adalah arus kas pendanaan yang meliputi pos-pos kewajiban dan ekuitas pemilik. Pengungkapan terpisah arus kas yang timbul dari aktivitas pendanaan perlu dilakukan sebab berguna untuk memprediksi klaim terhadap arus kas masa depan oleh para pemasok modal perusahaan (Tallier, 1989).

\section{Trading Volume Activity}

Volume perdagangan sendiri menurut (Ong, 2011) adalah salah satu parameter penting yang menunjukkan transaksi yang terjadi dalam aktivitas perdagangan pada suatu sesi atau mencerminkan jumlah saham yang berpindah tangan. Jumlah (volume) perdagangan yang tinggi menunjukkan minat partisipasi yang besar dari para pelaku pasar. Sedangkan jumlah (volume) perdagangan yangminim menunjukkan minat yang kurang dari pelaku pasar. Pendapat hampir serupa dengan pendapat dari (Debikel, 2011) menurutya, volume perdagangan merupakan suatu instrumen yang dapat digunakan untuk melihat reaksi pasar modal terhadap informasi melalui parameter volume saham yang diperdagangkan di bursa efek. 


\section{Pengembangan Hipotesis}

\section{Pengaruh Total Asset Turnover terhadap Trading Volume Activity.}

Rasio Total asset turnover mengukur seberapa baik efisiensi seluruh aktiva perusahaan digunakan untuk menunjang kegiatan penjualan. Total asset turnover yang tinggi mengindikasikan bahwa manajemen perusahaan dapat mendayagunakan seluruh aktiva yang dimilikinya untuk mendatangkan revenue bagi perusahaan dan hal ini pada gilirannya dianggap dapat meningkatkan keuntungan perusahaan. Total asset turnover yang tinggi berpotensi menarik investor untuk terus berinvestasi di perusahaan dan meningkatkan nilai saham. Semakin tinggi rasio ini menunjukkan bahwa semakin efisien dana yang tertanam di perusahaan. Dengan kata lain jumlah asset yang sama dapat memperbesar volume penjualan apabila total asset turnover ditingkatkan atau diperbesar (Syamsuddin, 2010). Vayanos (2005), mengatakan bahwa perusahaan dengan total asset turnover yang tinggi diminati oleh investor karena perusahaan tersebut memiliki probabilitas yang lebih tinggi untuk menjadi sangat likuid.

Hipotesis 1: Total Asset Turnover berpengaruh signifikan terhadap Trading Volume Activity.

\section{Pengaruh Debt Equity Ratio terhadap Trading Volume Activity.}

Debt equity ratio merupakan perbandingan antara hutang dengan modal sendiri yang digunakan oleh perusahaan. Menurut teori struktur modal, nilai perusahaan akan meningkat dengan bertambahnya hutang perusahaan pada level tertentu. Penelitian yang dilakukan oleh Wira (2011), menyimpulkan bahwa rasio DER berpengaruh signifikan terhadap trading volume activity. Dimana pada periode penelitian yang ia lakukan, investor yakin bahwa perusahaan yang memiliki hutang yang lebih kecil akan memberikan nilai yang lebih baik, sehingga volume perdagangan saham lebih besar.

Hipotesis 2: Debt to Equity Ratio berpengaruh signifikan terhadap Trading Volume Activity.

\section{Pengaruh Cash Flow terhadap Trading Volume Activity.}

Penelitian tentang pegaruh laporan arus kas terhadap volume perdagangan saham telah banyak dilakukan sebelumnya. Penelitian terdahulu yang pertama membahas laba akrual yang memungkinkan untuk memprediksi arus kas masa depan. (Bowen, 1989) menguji kemampuan laba yang dibagi menjadi lima unsur arus kas dalam memprediksi arus kas masa depan dalam satu tahun kedepan dari kegiatan operasi. Mengungkapkan data pada penelitiannya, hasilnya menunjukkan bahwa unsur-unsur arus kas memiliki kemampuan memprediksi yang lebih kuat dalam memprediksi arus kas dari operasi dari pada laba. Arus kas yang tinggi juga akan meningkatkan volume perdagangan saham dan saham perusahaan akan lebih likuid.

Hipotesis 3 : Cash Flow berpengaruh signifikan terhadap Trading Volume Activity.

\section{Pengaruh Total Asset Turnover terhadap Return.}

Total asset turnover merupakan rasio aktivitas yang menggambarkan aktivitas yang dilakukan perusahaan dalam menjalankan operasinya baik dalam kegiatan penjualan, pembelian dan kegiatan lainnya. Rasio ini dinyatakan sebagai perbandingan penjualan dengan berbagai elemen aset. Elemen aset sebagai pengguna dana seharusnya bisa dikendalikan agar bisa 
dimanfaatkan secara optimal. Semakin efektif dalam memanfaatkan dana semakin cepat perputaran dana tersebut, karena rasio aktivitas umumnya diukur dari perputaran masing-masing elemen aset (Riyanto, 2011).

Menurut Aprisilya (2016) semakin tinggi rasio total asset turnover, berarti semakin efisien penggunaan seluruh aktiva di dalam menghasilkan penjualan. Maka dengan penjualan yang meningkat laba yang dihasilkan oleh perusahaan juga akan meningkat, sehingga laba berupa dividen yang siap dibagikan kepada investor juga akan meningkat. Bagi investor laba perusahaan yang meningkat maka akan memberikan return yang tinggi. Semakin tinggi rasio total asset turnover pada suatu perusahaan, maka investor akan tertarik untuk melakukan pembelian saham sehingga kesempatan untuk memperoleh return dapat direalisasikan.

Hipotesis 4 : Total Asset Turnover berpengaruh signifikan terhadap return.

\section{Pengaruh Debt to Equity Ratio terhadap Return.}

Peningkatan hutang diharapkan mampu menambah tingkat pengembalian perusahaan sehingga pada akhirnya mampu meningkatkan harga perusahaan tersebut melalui pemenuhan modal yang dibutuhkan perusahaan dalam rangka melancarkan kegiatan operasional perusahaan. Ketersediaan modal dapat digunakan perusahaan untuk ekspansi dan pengembangan usaha perusahaan sehingga perusahaan mampu bertahan dan berkembang lebih besar. Bila kinerja perusahaan meningkat maka minat investor terhadap perusahaan menjadi tinggi dan dampaknya terhadap return saham akan meningkat.

Penelitian yang dilakukan oleh Bhandari (1988) meneliti hubungan antara debt equity ratio dengan return. Hasil penelitian menunjukkan bahwa terdapat hubungan signifikan negatif antara debt equity ratio dengan return. Perusahaan yang memiliki modal lebih besar daripada utang tentunya lebih aman secara finansial menurut investor. Dengan total utang baik itu utang jangka pendek maupun jangka panjang, dapat di cover dengan modal yang dimiliki perusahaan. Tingkat utang yang terjaga dapat meningkatkan minat investor untuk membeli saham perusahaan sehingga kesempatan untuk memperoleh return dapat direalisasikan.

Hipotesis 5 : Debt to Equity Ratio berpengaruh signifikan terhadap return.

\section{Pengaruh Cash Flow terhadap Return.}

Aktivitas operasi adalah aktivitas penghasil utama pendapatan perusahaan. Penelitian yang dilakukan oleh (Suhairi, 2006) yang menguji komponen arus kas menemukan bukti bahwa komponen arus kas mempunyai pengaruh positif dengan expected return saham. Semakin tingginya arus kas (cash flow) yang dihasilkan oleh perusahaan setiap periode, maka hal ini dapat menarik minat investor untuk membeli saham perusahaan tersebut sehingga peluang untuk memperoleh return dapat direalisasikan.

\section{Hipotesis 6 : Cash Flow berpengaruh signifikan terhadap return.}

\section{Pengaruh Trading Volume Activity terhadap Return.}

Perhitungan trading volume activity dilakukan dengan membandingkan jumlah saham yang diperdagangkan dalam suatu periode tertentu dengan keseluruhan jumlah saham beredar di perusahaan tersebut pada kurun waktu yang sama Aprisilya (2016). Nilai dari trading volume activity berbanding lurus dengan likuiditas saham, dengan demikian semakin tinggi nilai trading 
volume activity sebuah saham mengartikan bahwa saham tersebut dapat dijual dengan mudah karena banyak yang bersedia membeli saham sehingga saham mudah dicairkan menjadi kas. Jones (2002) menemukan bahwa asset dengan likuiditas yang tinggi akan memberikan return yang tinggi pula.

Hipotesis 7 : Trading Volume Activity berpengaruh signifikan terhadap return.

\section{Trading Volume Activity Memediasi Hubungan Antara Total Asset Turnover dan Return.}

Total asset turn over menunjukkan seberapa efektif perusahaan menggunakan aset yang dimiliki untuk meningkatkan penjualan (revenue). Penelitian yang dilakukan oleh Jones (2002) menyimpulkan bahwa likuiditas yang tinggi akan memberikan return yang tinggi. Hal ini berarti trading volume activity berpengaruh positif signifikan terhadap return.

Apabila perusahaan efektif dalam penggunaan seluruh total asset untuk mendatangkan penjualan sehingga rasio total asset turnover meningkat setiap periodenya, maka akan menarik minat investor untuk membeli saham sehingga dapat menyebabkan meningkatnya volume perdagangan saham dan menjadi lebih likuid serta peluang untuk memperoleh return juga akan semakin terealisasi.

Hipotesis 8 : Trading Volume Activity dapat memediasi Total Asset Turnover dan Return.

\section{Trading Volume Activity Memediasi Hubungan Antara Debt Equity Ratio dan Return.}

Utang perusahaan dapat meningkatkan kinerja perusahaan. Utang perusahaan yang baik adalah utang yang dapat diterima tingkat toleransinya dan dalam penggunaannya dapat meningkatkan performa perusahaan. Sedangkan utang yang buruk adalah penggunaan utang tersebut hanya untuk membayar beban yang ditanggung oleh perusahaan dan tidak berdampak kepada kinerja perusahaan. Penelitian yang dilakukan oleh Wira (2011) menyatakan bahwa Debt equity ratio mempunyai pengaruh negatif terhadap trading volume activity. Demikian juga dengan penelitian yang dilakukan oleh Bhandari (1988) menyatakan debt to equity ratio mempunyai pengaruh negatif signifikan terhadap return.

Hipotesis 9 : Trading Volume Activity dapat memediasi Debt to Equtiy Ratio dan Return.

\section{Trading Volume Activity Memediasi Hubungan Antara Cash Flow dan Return.}

Laporan arus kas memiliki banyak informasi yang bisa digunakan oleh investor sebagai dasar pengambilan keputusan. Informasi yang terkandung dalam arus kas terdiri dari aktivitas operasi, aktivitas investasi dan aktivitas pendanaan. Dengan melihat informasi yang terkandung dalam laporan arus kas, para investor dan calon investor akan yakin terhadap pilihan investasi dan akan meningkatkan permintaan dan penawaran dalam perdagangan saham yaitu volume perdagangan (Bastomi, 2014). Penelitian yang dilakukan (Bowen, 1989) menyatakan bahwa unsur - unsur arus kas dari operasi memiliki kemampuan untuk memprediksi return dan meningkatkan volume perdagangan. Arus kas yang positif dan meningkat setiap periodenya akan meningkatkan minat investor untuk berinvestasi sehingga dapat meningkatkan volume perdagangan dan saham perusahaan semakin likuid sehingga peluang untuk memperoleh return juga akan semakin terealisasi.

Hipotesis 10 : Trading Volume Activity dapat memediasi Cash Flow dan Return. 


\section{METODOLOGI PENELITIAN}

\section{Jenis dan Sumber Data Penelitian}

Jenis data yang digunakan dalam penelitian ini adalah data sekunder, yaitu data-data yang disediakan oleh pihak lain. Data yang diperoleh berupa laporan keuangan perusahaan plantation yang dipublikasikan oleh Bursa Efek Indonesia (BEI) tahun 2016 - 2017. Populasi yang digunakan dalam penelitian ini adalah semua perusahaan plantation yang terdaftar di Bursa Efek Indonesia. Pengambilan sampel dilakukan dengan metode purposive sampling. Jumlah populasi 16 yang memenuhi kriteria sebanyak 14 perusahaan, maka data penelitian 14 × 8 kuartal yaitu 112 data.

\section{Metode Analisis dan Hipotesis Penelitian}

Pengujian pertama dengan uji statistic deskriptif, kemudian pengujian asumi klasik sebagai salah satu syarat untuk bisa menggunakan persamaan regresi adalah terpenuhinya uji asumsi klasik. Uji asumsi klasik dalam penelitian ini meliputi normalitas, heteroskedastisitas, autokorelasi dan multikolinieritas. Lanjutan pengujian untuk metode analisis yang digunakan adalah analisis jalur (path analysis) dan uji sobel.

\section{HASIL PENELITIAN DAN PEMBAHASAN}

Adapun hasil penelitian untuk analisis jalur (path analysis) adalah sebagai berikut :

\section{Tabel 1.1 Hasil Regresi Persamaan Sub Struktur I}

\begin{tabular}{|c|c|c|c|c|c|c|}
\hline \multicolumn{7}{|c|}{ Coefficients ${ }^{a}$} \\
\hline \multirow[t]{2}{*}{ Mode } & & \multicolumn{2}{|c|}{ Unstandardized Coefficients } & $\begin{array}{c}\text { Standardized } \\
\text { Coefficients }\end{array}$ & $t$ & Sig. \\
\hline & & $B$ & Std. Error & Beta & & \\
\hline \multirow{4}{*}{1} & (Constant) & 13.281 & 6.184 & & 2.148 & .034 \\
\hline & LN_TATO & -1.104 & .334 & -.346 & -3.308 & .001 \\
\hline & LN_DER & .391 & .333 & .116 & 1.172 & .244 \\
\hline & LN_CF & .160 & .225 & .079 & .711 & .478 \\
\hline
\end{tabular}

a. Dependent Variable: LN_TVA

Dari hasil penelitian diatas ditemukan bahwa Total Asset Turnover (TATO) berpengaruh secara signifikan terhadap Trading Volume Activity (TVA) dengan koefesien beta sebesar $34,6 \%$.

Tabel 1.2. Hasil Regresi Persamaan Sub Struktur II

\begin{tabular}{|c|c|c|c|c|c|c|}
\hline \multirow[t]{2}{*}{ Mod } & & \multicolumn{2}{|c|}{ Unstandardized Coefficients } & \multirow{2}{*}{$\begin{array}{c}\begin{array}{c}\text { Standardized } \\
\text { Coefficients }\end{array} \\
\text { Beta }\end{array}$} & \multirow[t]{2}{*}{$\mathrm{T}$} & \multirow[t]{2}{*}{ Sig. } \\
\hline & & $\mathrm{B}$ & Std. Error & & & \\
\hline \multirow{5}{*}{1} & (Constant) & -.536 & 3.222 & & -.166 & .868 \\
\hline & LN_TATO & -.255 & .182 & -.178 & -1.401 & .167 \\
\hline & LN_DER & .329 & .161 & .243 & 2.040 & .046 \\
\hline & LN_CF & .002 & .117 & .003 & .020 & .984 \\
\hline & LN_TVA & .149 & .046 & .374 & 3.220 & .002 \\
\hline
\end{tabular}

a. Dependent Variable: LN_RETURN 
Dari hasil penelitian diatas Debt to Equity Ratio dan Trading Volume Activity berpengaruh secara signifikan terhadap Return Saham dengan koefesien beta sebesar $24,3 \%$ dan $37,4 \%$. Kemudian untuk melihat apakah variabel intervening yaitu trading volume activity dapat memediasi variabel independen dan dependen adalah dengan melakukan pengujian sobel dengan hasil sebagai berikut :

Tabel 1.3 Hasil Uji Sobel

\begin{tabular}{|l|c|c|}
\hline \multicolumn{1}{|c|}{ Keterangan } & t hitung & t tabel \\
\hline TATO -----> TVA ------> Return & $-2,26267$ & 1,98 \\
\hline DER----->TVA------> Return & 1,06 & 1,98 \\
\hline Cash Flow ------->TVA----->Return & 0,66 & 1,98 \\
\hline
\end{tabular}

Dari hasil penelitian diatas ditemukan bahwa nilai t hitung lebih kecil daripada t tabel yang artinya trading volume activity tidak dapat memediasi total asset turnover, debt to equity ratio dan cash flow terhadap return saham.

\section{REKOMENDASI KEBIJAKAN}

\section{Rekomendasi}

Berdasarkan hasil pengujian data yang diproses sesuai dengan tujuan penelitian ini, maka rekomendasi hasil penelitian ini antara lain :

1. Penggunaan aset untuk meningkatkan penjualan memiliki pengaruh yang signifikan terhadap jumlah saham yang diperdagangkan. Adapun pengaruhnya adalah sebesar $34,6 \%$.

2. Penggunaan utang perusahaan memiliki pengaruh yang signifikan terhadap penerimaan return saham. Adapun pengaruhnya adalah sebesar $24,3 \%$.

3. Tingkat jumlah saham yang diperdagangkan memiliki pengaruh yang signifikan terhadap penerimaan return saham. Adapun pengaruhnya adalah sebesar $37,4 \%$.

\section{Kebijakan}

Berdasarkan hasil penelitian dan interpretasi penelitian ini, maka peneliti memberikan saran sebagai rekomendasi kebijakan antara lain :

1. Dalam membuat keputusan investasi, sebaiknya investor tidak hanya melihat laporan publikasi internal saja, seperti laporan keuangan. Tetapi, aspek eksternal yang dapat mempengaruhi bisnis perusahaan juga harus diperhatikan, seperti : kebijakan moneter, kebijakan ekspor, kebijakan pemerintah, persaingan substitusi. Apabila aspek eksternal memberikan informasi yang positif dan didukung dengan fundamental perusahaan (laporan keuangan) juga memberikan informasi yang positif, maka investor dapat membuat keputusan investasi secara rasional. 


\section{DAFTAR PUSTAKA}

Aprisilya, Tiari \& Wisnu Mawardi. (2016). Analisis Pengaruh Total Asset Turnover, Book to Market Ratio, Debt Equity Ratio Terhadap Expected Return Dengan Trading Volume Activity Sebagai Variabel Intervening, p. 5-11.

Bastomi, A. Y. (2014). Pengaruh Informasi Laporan Arus Kas terhadap Volume Perdagangan Saham Pada Perusahaan Food and Beverage yang Tercatat di Bursa Efek Indonesia. Universitas Negeri Surabaya, p. 15-16.

Bhandari, L. C. (1988). Debt Equity Ratio and Expected Common Stock Returns : empirical evidence. The Journal of Finance, p. 10-13

Bowen, R. M., Tallier, D. B., \& Daley, L. (1989). Fundamental Information Analysis. Accounting Journal, p.56-60.

Chairiyah, M. (2013). Pengaruh asset growth, return on equity, total asset turnover, dan earning per share terhadap Beta Saham. Universitas Negeri Padang, p.8-14.

Copeland, T. E. (1979). Liquidity Changes Following Stock Splits. The Journal of Finance, p.1519.

Elfitri, W. (2012). Analisis kinerja perusahaan terhadap likuiditas saham pada perusahaan yang listing di Bursa Efek Indonesia. Jurnal Akuntansi dan Manajemen, p.8-16.

Ikatan Akuntansi Indonesia (2017). Standar Akuntansi Keuangan. Jakarta: Penerbit Salemba Empat.

Jama'an. (2008). Pengaruh Mekanisme Corporate. Universitas Diponegoro, p.29-37.

Jones, M. C. (2002). A Century of stock market liquidity and trading costs. Working Paper Colummbia University, p. 33-38.

Purwitajati, Endah. (2016). Pengaruh Debt to Equity Ratio pada Return Saham Dengan Ukuran Perusahaan Sebagai Pemoderasi, p.11-12.

Riyanto, B. (2011). Manajemen Keuangan. Yogyakarta: BPFE Yogyakarta, p-64-66.

Rohman, A. (2005). Pengaruh Langsung dan Tidak Langsung Arus Kas dan Laba Terhadap Volume Perdagangan Saham. Jurnal Akuntansi dan Auditing, p. 17.

Rowland Bismark Pasaribu, F. (2010). Value at risk portofolio. Jurnal akuntansi dan manajemen, p. 9-10.

Saribu, Ardin Dolok. 2011. Analisis Pengaruh Rasio Keuangan dan Total Asset TerhadapHarga Saham Dengan Beta Saham Sebagai Variabel Moderating （Studi

Empiris Pada Perusahaan Perbankan Yang Terdaftar di Bursa Efek Indonesia), Universitas Sumatera Utara. Medan, p. 14-18.

Suhairi, N. (2006). Pengaruh Kandungan Informasi Komponen Informasi, Komponen Arus Kas, Laba Kotor dan Size Perusahaan terhadap Expected Return Saham. Simposium Nasional Akuntansi, p.11-14.

Michell. 2006. Studi Empiris Mengenai Pengaruh Profitabilitas, Leverage dan Harga Saham terhadap Jumlah Dividen Tunai, Studi pada Perusahaan yang Terdaftar di Bursa Efek Jakarta. Jurnal Maksi Universitas Katolik Indonesia Atma Jaya, p.6.

Syamsuddin, L. (2010). Manajemen Keuangan Perusahaan. Jakarta: PT Raja Gravindo Persada, p. 17-23.

Vayanos, D. (2005). Transaction Costs and Asset Prices. The Review of Financial Studies, p. 2327. 